\title{
Kenyataan Penegakan Hukum di Indonesia dalam Perspektif Hukum dan Pembangunan: Hukum Harus Ditaati atau Ditakuti?
}

\author{
Nindya Putri Edytya \\ Fakultas Hukum, Universitas Negeri \\ Semarang \\ Jl. Kampus Timur, Sekaran, Gunungpati, \\ Kota Semarang, Jawa Tengah 50229 \\ Surel: nindya401@gmail.com
}

\author{
Reyhan Satya Prawira \\ Fakultas Hukum, Universitas Negeri \\ Semarang \\ J. Kampus Timur, Sekaran, Gunungpati, \\ Kota Semarang, Jawa Tengah 50229 \\ Surel: reyhansatyaprawira@gmail.com
}

\begin{abstract}
ABSTRAK
Hukum dan Pembangunan adalah studi yang terkait dengan keberadaan atau keabsahan hukum di negaranegara yang merupakan bagian dari Studi Pembangunan.

Bagi orang-orang Indonesia, keberadaan hukum tergantung pada bagaimana pemerintah menegakkan hukum di masyarakat. Oleh karena itu, perlu untuk membawa penegakan hukum menjadi ketat dan berwibawa pada sistem hukum Indonesia dalam masyarakat. Berdasarkan hal ini, meneliti penulis menggunakan metodologi penelitian yuridis - sosiologi yang meneliti aturan, konsep, pandangan masyarakat terhadap penegakan hukum di Indonesia.
\end{abstract}

RIWAYAT ARTIKEL

Article History

Diterima : 5 September 2019

Dipublikasi : 25 November 2019

\section{KATA KUNCI}

Keywords

Pembangunan Hukum, Penegakan

Hukum, Takut Hukum, Patuh

HOW TO CITE (saran perujukan):

Edytya, Nindya Putri \& Reyhan S. Perwira. (2019). "Kenyataan Penegakan Hukum di Indonesia dalam Perspektif Hukum dan Pembangunan: Hukum Harus Ditaati atau Ditakuti?", Lex Scientia Law Review. Volume 3 No. 2, November, hlm. 177-190

\section{PENDAHULUAN}

Manusia sebagai makhluk sosial yang zoon politicon (Aristoteles) dalam kehidupan sosial tidak mudah. Hal ini karena setiap manusia memiliki kebutuhan dan kepentingan sendiri yang sering bertentangan satu sama lain. Sebagai akibat dari perbedaan yang sering terjadi ketidakseimbangan atau ketidakcocokan dalam 
kehidupan sosial. Di sinilah aturan kehidupan manusia yang disebut hukum dibutuhkan di tengah-tengah masyarakat. Menurut Selznick, hukum berkaitan dengan upaya untuk mewujudkan nilai-nilai tertentu (Samsudin, 2012: 45). Oliver Wendel Holmes menyarankan bahwa "kehidupan hukum belum logika, ia memiliki pengalaman (Rahardjo, 2010: 7). Menurut Sudikno Mertokusumo, aturan hukum merupakan ketentuan atau pedoman tentang apa yang harus dilakukan (Mertokusumo, 2010: 7). Seperti yang bisa kita lihat dari pengaturannya, hukum adalah aturan keseluruhan bahwa setiap orang sosial harus mematuhi (Marwan dan Jimmy, 2009: 258).

Di alam, kedamaian dan ketenangan hidup yang dicapai jika masyarakat memberikan kontrol, pengawasan sosial, baik tertulis maupun tidak tertulis. Realistis, elemen-elemen kontrol sosial akan mengalami perubahan dan perkembangan baik evolusi dan revolusi sesuai dengan perkembangan masyarakat. Hukum dan moral memiliki hubungan dialektis antara dua aturan yang membentuk hubungan fungsional timbal balik antara hukum dan moral. Artinya, ada pengaruh timbal balik antara hukum dan moral dalam berbagai aspek kehidupan manusia, ada kontribusi moral terhadap hukum dan kontribusi hukum dengan moral.

Esensi hukum dalam hal ini adalah konsep hukum sebagai seperangkat nilainilai, prinsip-prinsip dan norma-norma perilaku yang berfungsi untuk mengatur perilaku manusia dalam kehidupan masyarakat yang ditegakkan dengan sanksi yang dapat dikenakan pada pelanggar untuk membangun ketertiban dan perdamaian (keadilan ) dalam kehidupan masyarakat. Esensi moral yang dalam hal ini adalah norma-norma moral, yaitu norma-norma yang menentukan apakah perilaku kita baik atau buruk dari sudut pandang etika. Oleh karena itu norma-norma moral adalah norma tertinggi, yang tidak dapat ditaklukkan oleh norma-norma lainnya. normanorma moral adalah kewajiban berdasarkan kesusilaan dan kesopanan (Basiang, 2009: 294).

Hukum telah menjadi kerangka kerja dan kosa kata untuk membangun dan memperdebatkan kebijakan pembangunan (Kennedy, 2006: 167), tetapi hukum dan pembangunan, yang mengeksplorasi hubungan antara hukum dan kemajuan ekonomi dan sosial (Kennedy, 2006: 177), adalah relatif tidak dikenal dan terbelakang sebagai bidang akademik meskipun dekade penelitian (Davis, 2008: 895). "Hukum" umumnya didefinisikan sebagai "tubuh aturan tindakan atau perilaku yang ditentukan dengan mengendalikan otoritas, dan memiliki kekuatan hukum" (1997) atau "aturan tertentu atau seperangkat aturan yang mengikat pada anggota masyarakat." Contoh hukum termasuk ketentuan undang-undang yang diadopsi oleh badan legislatif, termasuk konstitusi, peraturan yang diadopsi oleh badan-badan administrasi, dan tata cara yang diadopsi oleh pemerintah kota. Dalam konteks hukum dan pembangunan, "Hukum" mungkin lebih luas dari apa istilah ini dianggap sebagai berdasarkan karakteristik formalistik. Misalnya, mengikat preseden yudisial yang disebut sebagai "hukum" (kasus hukum) di negara-negara hukum umum, seperti Amerika Serikat dan Inggris, bahkan jika preseden tersebut tidak secara resmi 
dianggap "hukum" dalam yurisdiksi hukum sipil, seperti Perancis dan Jerman. Namun, jika preseden yudisial diikuti dengan kekuatan mengikat de facto, maka mereka dianggap "hukum" untuk studi hukum dan pembangunan di kedua hukum umum dan negara-negara hukum perdata. Para ahli telah mengakui keberadaan dan kekuatan norma-norma selain undang-undang dan kasus hukum (Macaulay, 1963).

Untuk tujuan hukum seperti Amerika Serikat dan Inggris, bahkan jika preseden tersebut tidak secara resmi dianggap "hukum" dalam yurisdiksi hukum sipil, seperti Perancis dan Jerman. Namun, jika preseden yudisial diikuti dengan kekuatan mengikat de facto, maka mereka dianggap "hukum" untuk studi hukum dan pembangunan di kedua hukum umum dan negara-negara hukum perdata. Para ahli telah mengakui keberadaan dan kekuatan norma-norma selain undang-undang dan kasus hukum (Macaulay, 1963). Untuk tujuan hukum seperti Amerika Serikat dan Inggris, bahkan jika preseden tersebut tidak secara resmi dianggap "hukum" dalam yurisdiksi hukum sipil, seperti Perancis dan Jerman. Namun, jika preseden yudisial diikuti dengan kekuatan mengikat de facto, maka mereka dianggap "hukum" untuk studi hukum dan pembangunan di kedua hukum umum dan negara-negara hukum perdata. Para ahli telah mengakui keberadaan dan kekuatan norma-norma selain undang-undang dan kasus hukum (Macaulay, 1963). Untuk tujuan hukum dan Para ahli telah mengakui keberadaan dan kekuatan norma-norma selain undang-undang dan kasus hukum (Macaulay, 1963). Untuk tujuan hukum dan Para ahli telah mengakui keberadaan dan kekuatan norma-norma selain undang-undang dan kasus hukum (Macaulay, 1963). Untuk tujuan hukum dan studi pembangunan, "hukum" juga mencakup beberapa norma-norma ini atau aturan informal disebut sebagai "hukum adat," yang secara konsisten diamati dengan opinio juris (Saussine, 2009).

Penegakan hukum (dalam arti kecil) adalah melakukan aturan kepada masyarakat. Tapi tugas dari penegak hukum tidak hanya melakukan itu secara normatif seperti hukum pidana bukanlah kebijakan untuk menghilangkan crimenormatively. Menurut Barda Nawawi Arief, Kebijakan penghapusan pidana merupakan bagian dari pertahanan sosial. Tujuan utama dari kebijakan kriminal adalah pertahanan sosial untuk mencapai kesejahteraan sosial. Kebijakan kriminal merupakan bagian dari kebijakan sosial untuk mencapai kesejahteraan sosial (Arief, 2001: 20). Berdasarkan PBB (Perserikatan Bangsa-Bangsa) Konggres untuk pemberantasan kriminal dan penghapusan pidana itu konteks dari kebijakan pembangunan sebagai global sosial. Penghapusan pidana dapat dilakukan melalui pendekatan kebijakan (kebijakan kriminal dan kebijakan sosial dan penghapusan pidana).

Sadar atau tidak, manusia dipengaruhi oleh aturan hidup bersama yang mengekang nafsu dan mengatur hubungan antara orang-orang. Aturan hidup memberikan penjelasan tentang tindakan yang dapat dilakukan dan tindakan yang harus dihindari. Aturan hidup memberikan panduan kepada orang-orang bagaimana mereka harus bersikap dan bertindak. Siapapun masyarakat yang dengan sengaja melanggar aturan hukum, akan dikenakan sanksi (sebagai akibat dari pelanggaran 
aturan hukum) dalam bentuk hukuman. kepatuhan masyarakat dengan aturan hukum dapat didorong oleh ketaatan pribadi anggota masyarakat untuk norma-norma moral yang sejalan dengan norma-norma hukum. Namun, kepatuhan masyarakat dengan aturan hukum dapat juga hanya didorong oleh rasa takut sanksi hukum yang akan dikenakan pada pelanggar hukum.

\section{Metode Penulisan}

Penelitian dalam makalah ini menggunakan jenis yuridis sosiologis penelitian. Tinjauan yuridis adalah dengan meninjau / menganalisis data dalam bentuk materi hukum, terutama bahan hukum primer dan sekunder. Dalam pendekatan yuridis sosiologis, hukum sebagai hukum dalam tindakan, digambarkan sebagai fenomena sosial empiris. Dengan demikian hukum tidak hanya diartikan sebagai jalinan nilainilai, keputusan resmi, terjalin aturan dan norma, hukum tertulis positif, tetapi juga dapat diartikan sebagai suatu sistem ajaran tentang kenyataan. Sebuah pendekatan yuridis sosiologis, yaitu dalam menangani masalah yang dibahas berdasarkan peraturan yang berlaku dan kemudian dikaitkan dengan fakta-fakta yang terjadi di masyarakat sehingga memperoleh pengetahuan hukum secara empiris dengan pergi langsung ke objek. Makalah ini menggunakan metode kualitatif yang dimaksudkan untuk memberikan data sedetail mungkin tentang manusia, keadaan atau gejala lainnya. Penelitian ini diharapkan dapat memberikan gambaran yang komprehensif dan sistematis diatur dari realitas penegakan hukum di Indonesia.

\section{PEMBAHASAN}

\section{A. Hukum dan Pembangunan}

Hukum dapat berfungsi sebagai alat untuk mempromosikan pembangunan. Pandangan pragmatis dan instrumental dari hukum dan sistem hukum dibagi oleh para sarjana yang berpikir bahwa reformasi hukum dapat menjadi sarana untuk memajukan tujuan pembangunan tertentu, seperti pembangunan ekonomi yang diukur dengan PDB suatu negara per kapita. Namun, ulama ini tidak selalu setuju pada bagaimana hukum dapat mempromosikan pembangunan. Divergensi ini sebagian besar didasarkan pada pandangan yang berbeda dari peran negara dalam mempromosikan pembangunan dalam pertumbuhan umum dan ekonomi pada khususnya (Prado, 2010: 3).

Salah satu aliran pemikiran pendukung peran yang kuat bagi negara dalam mempromosikan pembangunan. Konsep negara berkembang diciptakan untuk menggambarkan negara-negara yang ada intervensi yang kuat negara dalam ekonomi, perlindungan yang signifikan bagi industri nasional, dan regulasi berat perusahaan multinasional yang memutuskan untuk berinvestasi pada anak perusahaan di negaranegara tersebut. Beberapa contoh negara perkembangan sukses adalah Jepang,

https://journal.unnes.ac.id/sju/index.php/lsIr/ 
Singapura dan Korea Selatan. contoh tidak begitu sukses termasuk Brazil dan India pada 1970-an dan 1980-an (Evans, 1995). Dalam keadaan pembangunan, hukum dapat digunakan sebagai alat untuk intervensi negara dalam kegiatan ekonomi. Intervensi ini dapat di mengubah timah untuk pertumbuhan ekonomi.

Munculnya studi Hukum dan Pembangunan terkait dengan fenomena transplantasi hukum di banyak negara yang baru merdeka dalam melaksanakan pembangunan. Pada tahun 1960, banyak negara berkembang tidak membuang-buang waktu konsolidasi dan bekerja keras untuk membuat kebijakan untuk mensejahterakan rakyatnya. Elit politik dan pembuat kebijakan di Negara Berkembang berusaha untuk menyelaraskan negara mereka dengan mantan kekuatan kolonial mereka. Mereka ingin negara mereka untuk menjadi modern. Pada awalnya, dalam melaksanakan proses pembangunan, membahas hukum tidak diberi banyak perhatian. Banyak alasan yang dikemukakan. Dari hukum sebagai penghalang untuk pembangunan itu sendiri dengan peran hukum yang berbeda di negara-negara berkembang dengan negara-negara di Eropa atau negara-negara yang memiliki tradisi Eropa. Tapi kondisi ini perlahan-lahan berubah. Pemerintah dari banyak negaranegara Barat demi kepentingan ekonomi dan pelaku usaha di Negara Berkembang, mendorong (bahkan tekanan) bahwa pemerintah dari Negara Berkembang memperhatikan keberadaan fungsi hukum dikenal di negara mereka (Juwana, 2006: 213). Jadi itu merasa perlu untuk regulasi permanen dan mengikat.

Dari ini muncul upaya untuk transplantasi undang-undang dan lembagalembaga hukum dari Barat ke Negara Berkembang. Pada awalnya, pemerintah Amerika Serikat sangat agresif dalam usaha ini (Merryman: 453-473). Beberapa mengatakan “... jangka Hukum dan Pembangunan negara di Afrika, Amerika Latin, dan Asia. Upaya ini berpusat di sekitar upaya untuk mengekspor hukum gaya Amerika dan lembaga hukum untuk negara-negara ini pada teori bahwa undangundang tersebut dan institutations hukum sangat sentral pembangunan ekonomi "(Ngugi, 2005: 599).. Dalam adopsi, telah terjadi penyimpangan dari tujuan awal untuk memodernisasi sistem hukum negara berkembang untuk pembangunan ekonomi. Apa dilakukan secara tepat meminta pemerintah negara-negara berkembang untuk mengadopsi suara bulat sistem hukum Amerika.

Dalam perkembangannya, studi Hukum dan Pembangunan telah kembali ke tujuan utamanya, sebagai kutipan berikut berbunyi "Selama hukum tahun sepuluh terakhir dan ekonomi telah berfokus pada bagaimana undang-undang dan prosedur hukum mempengaruhi pertumbuhan ekonomi dan pembangunan di negara-negara miskin" (Buscaglia dan Ratliff, 2000: vii). Hukum dan hukum lembaga di Asia berubah dalam menanggapi kebijakan ekonomi. Ketika kebijakan ekonomi diperkenalkan yang memberi aktor non-negara peran yang lebih besar dalam membuat keputusan alokasi, hukum dan perannya dalam pembangunan ekonomi Asia menjadi semakin mirip dengan Barat. Tidak hanya hukum substantif, tetapi juga proses hukum dan lembaga menanggapi perubahan ini (Pistor, 1998: 18). Berdasarkan ini, dapat dipertanyakan dalam konteks Indonesia. 
Berdasarkan ini, dirasakan perlunya penelitian yang meneliti penegakan hukum. Studi Hukum dan Pembangunan sejauh ini belum menyentuh masalah penegakan hukum. Sebagian besar masalah yang dibahas adalah hal yang berkaitan dengan peraturan perundangan dan lembaga-lembaga hukum. Pengalaman menunjukkan Indonesia bahwa jika undang-undang dan peraturan telah direformasi dan lembaga hukum telah dibentuk, hukum tidak bekerja jika penegakan hukum sangat lemah (Juwana, 2006: 220).

\section{B. Penegakan Hukum}

Pada dasarnya, manusia bertindak makhluk yang tidak hanya merespon tetapi juga bertindak dan dengan tindakan ini membuat unit kegiatan yang untuk menghilangkan kebingungan, kecemasan, dan membangun rasa percaya diri, dan gairah dalam hidup. Namun, semuanya bekerja dengan kekerasan, kenajisan, kesepian, prinsip hidup yang pendek, penuh dengan ketakutan, ketika tidak ada sistem sosial (aturan sosial) untuk disiplin dan mengatur, keberadaan undangundang atau peraturan sebagai alat kontrol ( Utsman, 2013: 185).

Penegakan hukum merupakan upaya untuk mewujudkan ide-ide hukum dan konsep yang orang mengharapkan untuk menjadi kenyataan. Penegakan hukum adalah proses yang melibatkan banyak hal (Dellyana, 1988: 32). Penegak hukum positif dalam praktek seperti itu harus dipatuhi. Oleh karena itu, memberikan keadilan dalam kasus berarti memutuskan hukum di concreto dalam menjaga dan menjamin ketaatan hukum materi dengan menggunakan metode prosedural yang ditetapkan oleh hukum formal.

Definisi penegakan hukum juga dapat diartikan sebagai administrasi hukum oleh aparat penegak hukum dan oleh siapa saja yang memiliki minat sesuai dengan kewenangan masing-masing sesuai dengan hukum yang berlaku. penegakan hukum pidana adalah proses terpadu yang dimulai dengan penyelidikan, penangkapan, penahanan, percobaan dari ujung terdakwa dan dengan keyakinan terpidana (Husen, 1990: 58). Menurut Soerjono Soekanto, mengatakan bahwa penegakan hukum merupakan kegiatan untuk menyelaraskan hubungan nilai-nilai yang ditetapkan dalam aturan yang solid dan sikap tindakan sebagai rangkaian terjemahan nilai tahap akhir untuk menciptakan dan memelihara perdamaian asosiasi kehidupan (Soekanto, 1983: 35).

Penegakan hukum dimaksudkan untuk meningkatkan ketertiban dan kepastian hukum dalam masyarakat. Hal ini dilakukan dengan mendisiplinkan fungsi, tugas dan wewenang lembaga-lembaga yang bertugas menegakkan hukum sesuai dengan proporsi dari lingkup masing-masing, dan berdasarkan sistem kerjasama yang baik dan mendukung tujuan yang ingin dicapai.

Menurut Moeljatno mengelaborasi berdasarkan pemahaman hukum pidana istilah yang mengatakan bahwa penegakan hukum merupakan bagian dari keseluruhan hukum yang berlaku di suatu Negara yang memegang unsur-unsur dan aturan, yaitu (Moeljatno, 1993: 23):

\section{https://journal.unnes.ac.id/sju/index.php/lsIr/}


1. Menentukan tindakan yang tidak boleh dilakukan dengan ancaman atau sanksi berupa hukuman tertentu bagi mereka yang melanggar larangan.

2. Menentukan cara apa bagi mereka yang melanggar larangan dapat dikenakan atau dihukum sebagai terancam.

3. Menentukan cara apa pengenaan kejahatan dapat dilakukan jika orang yang diduga telah melanggar larangan.

Tingkat perkembangan masyarakat di mana hukum ditegakkan mempengaruhi pola penegakan hukum, karena dalam masyarakat modern yang rasional dan memiliki tingkat tinggi spesialisasi dan diferensiasi organisasi penegakan hukum juga semakin kompleks dan sangat birokratis. Sebuah studi sistematis penegakan hukum dan keadilan secara teoritis efektif jika 5 pilar hukum berjalan dengan baik yaitu: instrumen hukum, aparat penegak hukum, faktor warga yang terkena lingkup peraturan hukum, faktor budaya, sarana dan fasilitas faktorfaktor yang dapat mendukung pelaksanaan hukum (Sanyoto, 2008: 191).

\section{Penegakan Hukum di Indonesia}

Penegakan hukum mencapai ide-ide pengembangan hukum disebutkan bahwa Indonesia adalah negara hukum bukan sebagai negara tanpa hukum. Ini berarti bahwa semua kegiatan harus diatur oleh hukum. Penelitian ini mencoba untuk menemukan jawaban bagaimana penerapan hukum membuat peran atau fungsi hukum sebagai penyedia jasa sosial dalam penegakan hukum (Friedman, 1969: 76). Sebenarnya hukum adalah aturan yang ideal tentang norma harus dilakukan. Ketika hukum diterapkan dalam masyarakat yang merupakan proses dari konkretisasi tetapi masih abstrak. Dalam hukum dogmatis hukum harus menghadiri penerapan hukum. Ini berarti kita harus paham tentang faktor-faktor yang mempengaruhi. Dan faktor utama adalah manusia. Menurut Satjipto Rahardjo, dalam hubungan sosial ada model sosial dan pembuat hukum adalah refleksi dari model sosial (Rahardjo, 1980: 40).

Chambliss dan Seidmann berbeda dua model social, mereka nilai konsensus dan konflik sosial. Untuk nilai konsensus, itu seperti tidak ada konflik di masyarakat karena mereka memiliki Greement atau concencus atau nilai. Dalam model kedua, karater dari konflik sosial adalah perubahan dan konflik. Ada banyak kesan di masyarakat. Schyut, ada dua kemungkinan untuk memecahkan konflik mereka, conflictoplossing dan conflictversterking (Soemitro, 1985: 31). Jika kita amati, penegakan hukum di Indonesia masih belum berjalan dengan baik dan sangat mengkhawatirkan. Masalah penegakan hukum selalu cenderung ketimpangan interaksi dinamis antara aspek hukum dalam harapan atau das sollen, dan aspek penerapan hukum dalam realitas das sein (Rifah, 2015: 40).

Jika dilihat dari penegakan hukum secara empiris yang melihat penegak hukum langsung ke realitas dalam masyarakat dengan mengukur apakah hukum berhasil mengarahkan perilaku petugas masyarakat dan penegak hukum berhasil menegakkan hukum, maka dalam kenyataannya, hukum masih tidak efektif 
(Widowati ) penegakan hukum di Indonesia, yang masih jauh dari apa yang diharapkan, tidak lepas dari pengaruh politik dalam hukum. Ini tidak hanya mempengaruhi penegakan hukum, tetapi juga karakteristik produk hukum dan proses manufaktur. Pelaksanaan fungsi dan penegakan hukum tidak selalu sejalan dengan perkembangan strukturnya. Hal ini jika ukuran pembangunan hukum di Indonesia adalah penyatuan dan kodifikasi hukum, seiring berjalannya waktu produktivitas legislasi meningkat.

Pembawa hukum praktis yang dapat berupa parlemen, keadilan, lembaga bantuan hukum, dan pejabat pemerintah mengisi sistem hukum bangunan di Indonesia dalam struktur hukum dan melaksanakan pembentukan hukum dalam mengembangkan substansi hukum. Dan yang tidak kalah penting adalah budaya hukum itu sendiri yang memiliki efek signifikan pada baik atau buruk penegakan hukum di Indonesia. Berapa banyak manfaat hukum dapat dibentuk dalam mewujudkan nilai-nilai keadilan sosial yang merupakan perwujudan dari nilai-nilai Pancasila itu sendiri.

\section{Realitas Penegakan Hukum di Indonesia}

Penulis tidak bisa menjelaskan efektivitas hukum tanpa membahas terlebih dahulu hukum di tingkat normatif (hukum dalam buku-buku) dan hukum di tingkat realitas (hukum dalam tindakan), karena tanpa membandingkan dua variabel tersebut tidak mungkin untuk mengukur tingkat efektivitas hukum . Donald Hitam berpendapat bahwa efektivitas hukum adalah masalah sentral dalam sosiologi hukum diperoleh dengan membandingkan realitas hukum dalam teori dengan realitas hukum dalam praktek sehingga ada kesenjangan antara keduanya. hukum dianggap tidak efektif jika ada perbedaan antara dua (Aziz, 2012: 23). Perkembangan penegakan hukum di Indonesia masih belum berjalan dengan baik, salah satunya adalah karena penegakan hukum yang masih ditafsirkan sebagai penegak hukum hanya agar keadilan prosedural digunakan sebagai acuan dalam proses penegakan hukum. Bila dilihat dari pendekatan filosofis, kemudian pada dasarnya tujuan penegakan hukum adalah untuk menyadari apa hukum yang ingin dicapai. Inti dari tujuan hukum itu sendiri terletak pada keadilan. Pancasila menjadi dasar filsafat, pandangan hidup, dasar negara, dan sumber tertib hukum Indonesia yang menjiwai hukum Indonesia yang menjadi pembenaran bagi perkembangan hukum di Indonesia. Nilai-nilai Pancasila harus dilaksanakan di dan sumber tertib hukum Indonesia yang menjiwai hukum Indonesia yang menjadi pembenaran bagi perkembangan hukum di Indonesia. Nilai-nilai Pancasila harus dilaksanakan di dan sumber tertib hukum Indonesia yang menjiwai hukum Indonesia yang menjadi pembenaran bagi perkembangan hukum di Indonesia. Nilai-nilai Pancasila harus dilaksanakan di realitas penegakan hukum di Indonesia yang dilakukan sesuai dengan ajaran agama dan adat istiadat masyarakat Indonesia.

Bagi orang-orang Indonesia, kekuatan penegakan hukum oleh otoritas akan

https://journal.unnes.ac.id/sju/index.php/lsIr/

Copyrights (c) 2018. UKM Lex Scientia, Fakultas Hukum Universitas Negeri Semarang 
menentukan persepsi keberadaan hukum. Jika penegakan hukum oleh otoritas lemah, orang akan melihat hukum tidak ada dan seolah-olah mereka di hutan. Jika tidak, jika penegakan hukum oleh otoritas yang kuat dan dilaksanakan secara konsisten, maka mempersepsikan masyarakat hukum ada. Dalam konteks seperti itu, masyarakat Indonesia masih pada tingkat masyarakat yang "takut" hukum dan tidak dapat dikategorikan sebagai masyarakat yang "taat" hukum. Bagi orang-orang yang takut hukum, orang tidak akan tunduk kepada hukum jika penegak hukum lemah, tidak konsisten dan tidak dapat dipercaya. Oleh karena itu, penegakan hukum yang tegas dan berwibawa dalam kehidupan hukum masyarakat Indonesia diperlukan.

Ada ilustrasi sederhana yang dapat dikemukakan untuk membedakan orangorang yang taat hukum dari orang-orang yang takut hukum. ilustrasi adalah, dalam UU Lalu Lintas yang disahkan pada tahun 1992 ketentuan yang terdapat pada penggunaan sabuk pengaman (UU No. 14 Tahun 1992 Pasal 23, ayat 1 juncto Pasal 61 ayat 2 mengenai Lalu Lintas dan Angkutan Jalan. Namun dalam kenyataannya, di Jakarta itu hanya pada tahun 2004 bahwa polisi lalu lintas diberlakukan aturan ini sehingga orang-orang yang digunakan sabuk pengaman. Sikap untuk menggunakan sabuk pengaman karena mereka mematuhi UU Lalu Lintas atau karena mereka takut polisi lalu lintas, bahkan takut denda damai mahal yang akan (Juwana, 2006: 221). Berdasarkan hal ini, penulis meneliti langsung ke masyarakat untuk mengetahui jawaban atas pertanyaan-pertanyaan ini. Penulis meneliti menggunakan teknik random sampling dengan total 100 responden. Berikut adalah hasil penelitian yang penulis dapatkan:

\begin{tabular}{|l|l|}
\hline \multicolumn{2}{|c|}{$\begin{array}{c}\text { Intensitas penegakan hukum di Indonesia } \\
\text { (Menurut Responden) }\end{array}$} \\
\hline & catatan: \\
& Biru: Kuat \\
& Merah: \\
& Medium \\
& Kuning: \\
& Lemah \\
\hline $54,2 \%$ & \\
\hline
\end{tabular}



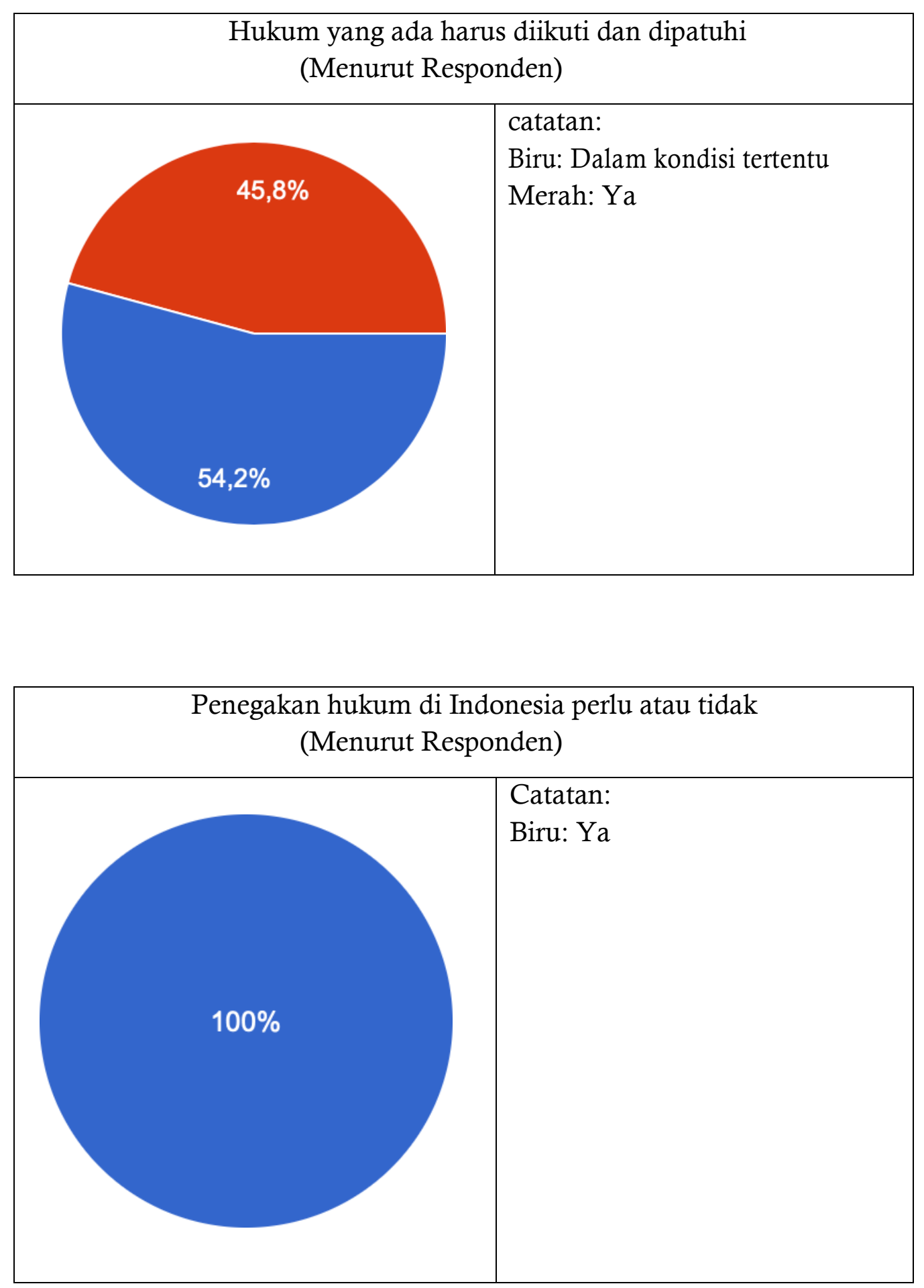


\begin{tabular}{|l|l|}
\hline \multicolumn{2}{|c|}{$\begin{array}{l}\text { Alasan mengapa penegakan hukum diperlukan dalam } \\
\text { masyarakat } \\
\text { (Menurut Responden) }\end{array}$} \\
\hline \\
\hline $6,5 \%$ & $\begin{array}{l}\text { Biru: Untuk itu Demi } \\
\text { dari itu pembentukan } \\
\text { masyarakat yang tertib } \\
\text { Kuning: Sebagai acuan bagi } \\
\text { masyarakat di negara } \\
\text { Merah: Sebagai representasi dari } \\
\text { negara dalam masyarakat } \\
\text { Warna lainnya: Alasan lain }\end{array}$ \\
\hline
\end{tabular}

\begin{tabular}{|l|l|}
\hline \multicolumn{3}{|c|}{$\begin{array}{c}\text { Alasan untuk mengikuti hukum } \\
\text { yang berlaku } \\
\text { (Menurut Responden) }\end{array}$} \\
\hline $93,2 \%$ & $\begin{array}{l}\text { Biru: Hukum itu menakutkan, } \\
\text { saya takut hukuman dari pihak } \\
\text { berwenang, jadi saya mengikuti } \\
\text { aturan hukum. } \\
\text { Merah: Hukum ada untuk } \\
\text { ditaati, apakah atau tidak } \\
\text { berwenang. }\end{array}$ \\
\hline
\end{tabular}




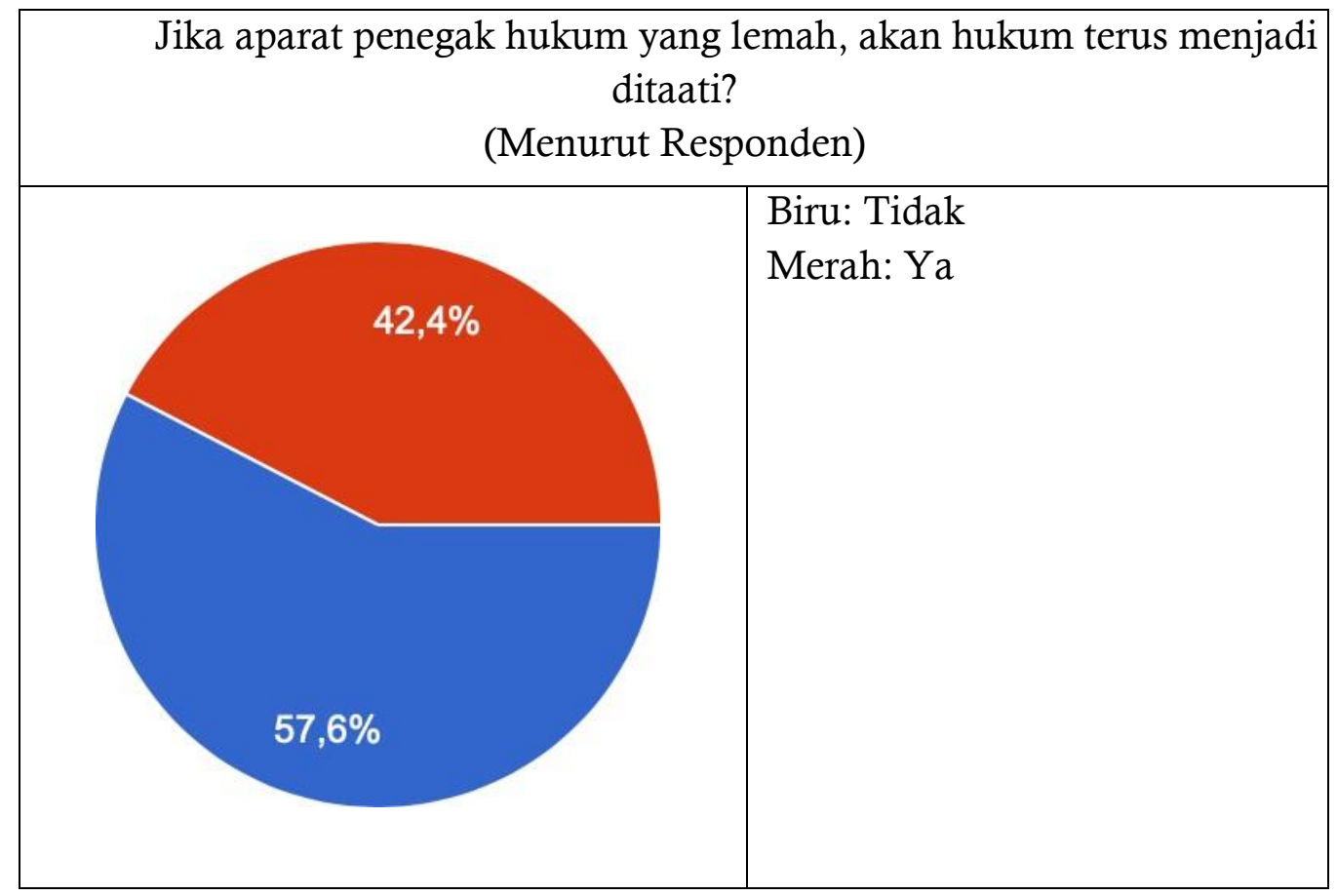

\section{KESIMPULAN}

Berdasarkan penelitian ini, data dan kesimpulan yang diperoleh benar bahwa orang mengikuti aturan hukum yang berlaku karena rasa "takut" daripada "ketaatan". Mematuhi hukum bukan tingkat tertinggi dalam hidup. Level tertinggi dari hidup adalah ketika setiap individu dalam masyarakat sadar sesuai dengan tujuan hukum. Sayangnya saat ini, masyarakat Indonesia masih jauh dari yang dikategorikan sebagai masyarakat di mana hukum telah terinternalisasi dalam sikap individu. Realitas saat ini adalah bahwa fungsi penegakan hukum sebagai instrumen untuk membuat orang takut hukum, yang diharapkan akan tunduk pada hukum. Namun, penegakan hukum sebagai instrumen telah terpukul dengan berbagai masalah akut. Masalah ini menyebabkan penegakan hukum menjadi lemah dan hukum dianggap sebagai mati. 


\section{DAFTAR PUSTAKA}

Arief, Barda Nawawi. 2001. Masalah Penegakan Hukum dan Kebijakan The Pidana Penghapusan. Bandung: Citra Aditya.

Aziz, Noor Muhammad. 2012. Urgensi Penelitian Dan Pengkajian Hukum Dalam Pembentukan Peraturan perundang-Undangan. Rechts Vinding, Vol. 1, No 1.

Basiang, Martina. 2009. Kontemporer Law Dictionary. Jakarta: Red \& White Publishing.

Black Law Dictionary 884. 1997.

Buscaglia, Edgardo dan William Ratliff. 2000. Hukum dan Ekonomi di Negara Berkembang. Stanford: Hoover Institution Press.

Davis, Kevin E. Dan Michael Trebilcock. 2008. "Hubungan antara Hukum dan Pembangunan: Optimis vs Skeptis”. 56 AM.J. COMP. L. 895.

Dellyana, Shant. 1988. KONSEP Penegakan Hukum. Yogyakarta: Liberty.

Evans, Peter. 1995. Tertanam Otonomi: Amerika dan Industri Transformasi. Princeton: Princeton University Press.

Friedman, Lawrence M. 1969. Hukum dan Ilmu Perilaku. Indianapolis: The Bobbs, Herril.

Husen, Harun M. 1990. Kejahatan Dan Penegakan Hukum Di Indonesia. Jakarta:Rineka Cipta.

Juwana, Hikmahanto. 2006. "Penegakan Hukum hearts Hukum Kajian dan Pengembangan: Masalah Dan fundamen Bagi Solusi di Indonesia”. Jurnal Indonesia Hukum Internasional, Vol 3 No 2.

Kennedy, David. 2006. "Rule of Law" Pilihan Politik, dan Pembangunan Common Sense, Dalam Hukum Baru dan Pembangunan Ekonomi: Sebuah Kritis Appraisal, 167 (David M. Trubek dan Alvaro Santos Eds). New York: Cambridge University Press.

Kennedy, Scott. "The Dialektika Hukum dan Pembangunan, Hukum Baru dan Pembangunan Ekonomi”. Catatan Supra 1.

Macaulay, Stewart. 1963. "Non-Kontrak Hubungan Bisnis: Sebuah Studi Awal". 28 AM. SOC. PUTARAN. 55.

Marwan Dan Jimmy P. 2009. Kamus Hukum. Surabaya: Realitas Publisher. Merryman, John Henry. "Perbandingan Hukum dan Perubahan Sosial: On The

Origins, Style, Tolak \& Kebangkitan gerakan Hukum dan Pembangunan". American Journal Perbandingan Hukum.

Mertokusumo, Sudikno. 2010. Mengenal Hukum. Yogyakarta: Universitas Atmajaya.

Moeljatno. 1993. Asas-asas Hukum Pidana. Surabaya: Putra Harsa. 
Ngugi, Joel M. 2005. "Kepolisian Reformasi Neo-liberal: Aturan Hukum sebagai Enabilishing dan Wacana Membatasi”. International Journal Econ. L, 26.

Pistor, Katharina dan Philip A. Wellons. 1998. Peran Hukum dan Lembaga Hukum di Asia Pembangunan Ekonomi 1960-1995. Hong Kong: Oxford University Press (Cina).

Prado, Mariana Mota. 2010, Apa hukum \& Pengembangan ?. Revista Argentina de Teoria Juridica, Volume 11.

Rahardjo, Satjipto. 1996. Ilmu Hukum. Bandung: Citra Aditya Bakti Rahardjo, Satjipto. 2010. Penegakan Hukum Progresif. Jakarta: PT. Kompas Gramedia Nusantara.

Rif 'ah. 2015. "Penegakan Hukum di Indonesia: Sebuah Harapan Dan Kenyataan". Jurnal Justitia Islamica, Vol. 12 / No.1.

Samsudin, M. 2012. Budaya Hukum Hakim, Jakarta: Kharisma Putra Utama.

Sanyoto. 2008. "Penegakan Hukum di Indonesia". Jurnal Dinamika Hukum Vol 8 No 3.

Saussine, Amanda Perreau dan James Bernard Murphy. 2009. "The Nature of Hukum Adat: Hukum, Sejarah dan Filsafat Perspektif".

Soekanto, Soerjono. 1983. Faktor-faktor Yang Mempengaruhi Penegakan Hukum. Jakarta: UI Pres.

Utsman, Sabian. 2013. Dasar-Dasar Sosiologi Hukum. Yogyakarta: Pustaka Pelajar.

Widowati, Christiani. "Hukum sebagai Norma Sosial Memiliki Sifat Mewajibkan,"ADIL: Jurnal Hukum, Vol. 4 No. 1. 